ENTREPRENEURSHIP AND SUSTAINABILITY ISSUES

ISSN 2345-0282 (online) http://jssidoi.org/jesi/ 2020 Volume 8 Number 1 (September)

http://doi.org/10.9770/jesi.2020.8.1(66)
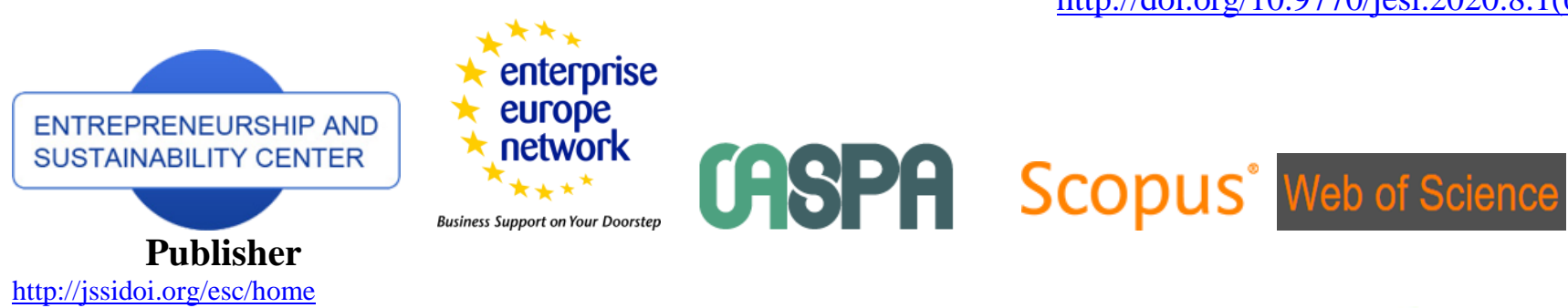

$\underline{\mathrm{http}: / / \text { jssidoi.org/esc/home }}$

Business Support on Your Doorstep

1) Clarivate

Analytics

\title{
TOURIST SPENDING AND PRODUCTIVITY OF ECONOMY IN OECD COUNTRIES - RESEARCH ON PERSPECTIVES OF SUSTAINABLE TOURISM*
}

\author{
Beata Gavurova ${ }^{1}$, Ladislav Suhanyi ${ }^{2}$, Martin Rigelsky ${ }^{3}$ \\ ${ }^{1}$ Faculty of Management and Economics, Tomas Bata University in Zlín, Mostni 5139, 76001 Czech Republic \\ ${ }^{2,3}$ Faculty of Management, University of Prešov, Konštantínova 16, 08001 Prešov, Slovakia \\ E-mails:I gavurova@utb.cz, ${ }^{2}$ ladislav.suhanyi@unipo.sk, ${ }^{3}$ martin.rigelsky@smail.unipo.sk
}

Received 12 May 2020; accepted 10 July 2020; published 30 September 2020

\begin{abstract}
Tourism represents the sector of services which is developing the most considerably and dynamically. However, its development is influenced by: trends in globalization, process of demographic aging, economic parameters, geographical conditions of a country, consumers, and other aspects. The following aspects contribute to its development: new destinations, markets, innovative activities in service sector, and also technological development. Tourism plays a significant economic role in a process of sustainable regional development, where it helps to develop low-growth regions. Monitoring and quantification of tourism outputs is a very complicated process. There also absents a quality database, which complicates a quantification of sector's efficiency and a creation of national and international benchmarking indicators that inform of sustainable tourism level. These aspects demand a realization of multi-dimensional analyses, which would examine causal relations between tourism factors and economic parameters of a country. The study's motivation was driven by all of the above-mentioned facts. It aims at researching an influence of tourism spending on OECD countries' productivity. Consequently, it evaluates their potential of the sector's sustainability. Multiple analytical procedures, which were determined by database availability, were performed in order to achieve the, research aim. The following analyses were performed besides the descriptive statistics: variance analysis of researched variables between individual years and OECD countries, context analysis, regression and cluster analyses. There were analysed 5 variables that characterize individual types of tourist spending: Business Tourism Spending, Domestic Tourism Spending, Leisure Tourism Spending, Outbound Travel \& Tourism Expenditure , Visitor Exports (Foreign Spending) and one variable that characterizes productivity during 2010 - 2018 for all OECD countries. Spending variables were standardized per 1,000 inhabitants of a given country and productivity was measured by GDP per capita, while both groups of variables were provided in USD (fair value). The analyses' results provided interesting findings. The regression models' outputs confirmed an influence of tourist spending on a country's productivity. All variables that indicate spending are significant. The cluster analysis's results allowed a selection of countries into four groups. There is two huge clusters and other two clusters represent only one countries in specific cluster. Luxemburg and Iceland give us different values than countries in other clusters. The countries with higher rank are as follows: Australia (AUS), Austria (AUT), Belgium (BEL), Canada (CAN), Germany (DEU), Denmark (DNK), Finland (FIN), France (FRA), Unites Kingdom (GBR), Switzerland (CHE), Ireland (IRL), Italy (ITA), Netherland (NLD), Norway (NOR), New Zealand (NZL), Sweden (SWE), United States (USA), Island (ISL) and Luxembourg (LUX). On the other hand, the countries with lower rank are as follows: Czech Republic CZE, Spain (ESP), Estonia (EST), Greece (GRC), Hungary (HUN), Chile (CHL), Israel (ISR), Japan (JPN), Korea (KOR), Lithuania (LTU), Latvia (LVA), Mexico (MEX), Poland (POL), Portugal (PRT), Slovak Republic (SVK), Slovenia (SVN) and Turkey (TUR). These findings provide a space for a deeper research of effect between determinants of tourism development and economic indicators, while they enable to reveal a space for a growth of countries' productivity that would provide a sustainability in tourism sector.
\end{abstract}

\footnotetext{
*The research was supported by the Research and Development Agency, GAAA under the contract No. 21/2020:
}

"Management, business risk and the firm bankruptcy in the segment of SMEs". 


\section{ENTREPRENEURSHIP AND SUSTAINABILITY ISSUES}

ISSN 2345-0282 (online) http://jssidoi.org/jesi/

2020 Volume 8 Number 1 (September)

http://doi.org/10.9770/jesi.2020.8.1(66)

Keywords: tourist spending; sustainable tourism; sustainable development; productivity; expenditures; tourism; OECD

Reference to this paper should be made as follows: Gavurova, B., Suhanyi, L., Rigelsky, M. 2020. Tourist spending and productivity of economy in OECD countries - research on perspectives of sustainable tourism. Entrepreneurship and Sustainability Issues, 8(1), 983-1000. http://doi.org/10.9770/jesi.2020.8.1(66)

JEL Classifications: L83, F43, R11

\section{Introduction}

At present, tourism is characteristic of a quantitative growth of domestic and foreign visitors' number, significant (predominantly non-controlled) growth of tourism infrastructure, travelling for long distances and geographical expansion. Tourism represents such activities that are linked to place of origin, i.e. region, or destination. Thus, it is considered as one of the key engines of a region's economic growth.

Stimulating the growth of the productivity by the development of the tourism industry has frequently been taken as an important economic development strategy for the majority of developing countries (Seghir et al., 2015). As a result of the increasing importance of the tourism sector for the country's economy, the matter to explore the relationship between tourism spending and the productivity of the country has drawn more recent attention. It is also because the understanding of the causal relationship between them is highly important in the design and implementation of tourism policies. According to Oh (2005) the causal relationship between tourism spending and economic performance has been synthesized into three assumptions within the literature: 1) the hypothesis of tourism-led economic growth; 2) the hypothesis of economic-driven tourism growth; and 3) the reciprocal causal hypothesis. The present study examines separately and focuses on the understanding of the causality outlined in the first assumption, but fully accepts the reciprocal effect that can be present. Tourism is a sector of the economy, and thus, without any doubt, belongs to the sphere of business, with its various subdivisions. The importance of the issue in association to the fields of management is underlined by Stefko and Nowak (2014). It is also a branch of science, although on account of its interdisciplinary composition, it is not an independent field of science (Sawicki, 2016). The impact of tourism in the global economy is significant. Being a worldwide phenomenon, tourism has become one of the fastest growing sectors of the global economy (Kasim, 2006). Further, Ritchie and Crouch (2003) argue that the development of tourism in a destination or country should be sustainable from an economic, ecological, socio-cultural perspective, to be competitive (Dibra, 2015). Being competitive, tourism can contribute successful to the development (UNWTO, 2013).

The facts given in the following sections of the study point to heterogeneous structure of tourism, real limitation of its individual categories, as well as correlation among them. Consequently, it is very important to explicitly and accurately define chosen categories, their procedural trajectories and relations among them.

The main motivation to realize this research was a very current issue of a research of economic relations in tourism. The study's aim was to examine causal relations between determinants of tourism development and economic indicators, and to reveal a space for a growth of OECD countries' productivity and a sustainability of tourism sector, as well as entire economy. The results represent a valuable platform for creators of regional, national policies, as well as creators of strategic-development plans and concepts. 


\section{ENTREPRENEURSHIP AND SUSTAINABILITY ISSUES}

ISSN 2345-0282 (online) http://jssidoi.org/jesi/

2020 Volume 8 Number 1 (September)

http://doi.org/10.9770/jesi.2020.8.1(66)

\section{Theoretical background}

Indicators, such as internal tourism consumption and spending on internal tourism represent tourism influence on a state's economy on the demand side. The indicator, spending on internal tourism, is a part of internal tourism consumption.

The tourism is exanimated through the following perspectives in this study: Business Tourism, Domestic Tourism, Leisure Tourism, Outbound Tourism (Outbound Travel), Inbound Tourism (Visitor Exports).

Business tourism corresponds to very different domains, its field enrolling alike: global diplomatic meetings and meetings between representatives of different countries, economic and trade negotiations meetings, meetings for the exchange of scientific and technical information and communication of the results of certain research and development projects, cultural and educational meetings, as well as events specific to various forms of cultural manifestation, sports competitions, etc. (Nicula, Popsa, 2014). Despite attempts by individual authors to define business tourism, most of them adopt the criteria of the "business trip" (Sawicki, 2016). Swarbrooke and Horner (2001, p.21) distinguish the following business trip or event categories: conferences and meetings (organisations and companies), congresses, training, fairs and exhibitions, incentive travel, promotional events, short-term workrelated relocation (contract, secondment), lecturer or student exchange programmes, commuting to work outside the residential area, individual business trips, diplomatic missions, tasks performed by the military away from their permanent base, delivery of goods to customers, charity assistance to Non-Government Organisations. Taking into account the approaches of different authors we can conclude and being inspired by Nicula and Popsa (2014) we can understand a business tourism as a form of tourism for commercial, governmental or educational purposes, with the recreational (leisure) part as a secondary motivation. There are many kinds of business tourism: individual trips, group trips, displacements at events (Meetings, Incentives, Conventions, Exhibitions (MICE), team building and training trips.

Leisure tourism is considered as very important in terms of mental, physical and emotional health, but our understanding of how this works remains limited, its practices can be significant in friendship, communitybuilding, empowerment and identity as enjoyment (Crouch, 2013). We have to distinguish between the following terms 'leisure' and 'leisure tourism'. Leisure, as 'free time' (and not as a specific activity), might be a necessary precondition for modern leisure tourism. Travel is the distinguishing mark, which tends to make it into an extraordinary activity (Graburn 1989), in contrast to other, more ordinary, everyday leisure activities, which do not involve travel (Cohen, 2010). Consequence that may stem from leisure tourism and recreation development is that price inflation and property prices may rise, making it increasingly difficult for those not participating in the development and thus benefiting from rising wages and profits to remain in the area - the economic displacement can occur (Tribe, 2015).

In most countries the domestic tourism is dominant with respect to international flows in terms of both size and economic contribution (Massidda, Etzo, 2012). It is stated that a vibrant domestic tourism sector can "cushion the industry from fluctuations of the international tourism market and bring stability and predictability in the industry" (Okello et al, 2012, p.79). The domestic tourism represents the largest part of worldwide travel spend (71.2\% in 2018) and had the strongest growth in developing nations, continues to support opportunities by spreading development and regional economic benefits and building national pride (using the last available data from WTTC, 2019). The continued growth in domestic tourism is linked to the trend for shorter holidays closer to home, a phenomenon referred to as ,staycation (Papatheodorou et al., 2010) and global trends indicate that tourism is becoming a regional/national rather than a global phenomenon (Kruger, Douglas, 2015). Domestic tourists with limited incomes generate numerous economic benefits, for example (Scheyvens, 2002, Samy, 2016): bringing economic benefits to areas not frequented by other tourists; less subject to seasonality than international tourism; spending more on locally produced goods with cheaper prices compared to imported luxury items; requiring small accommodation services with basic infrastructure therefore ensuring lower overhead costs and 


\section{ENTREPRENEURSHIP AND SUSTAINABILITY ISSUES}

ISSN 2345-0282 (online) http://jssidoi.org/jesi/ 2020 Volume 8 Number 1 (September) http://doi.org/10.9770/jesi.2020.8.1(66)

minimizing the need for imported goods; significant multiplier effect from relying on local skills and resources. Domestic and international tourism demand are often characterised by different patterns in terms of economic impacts and therefore should be analysed separately to capture their relationship with economic growth (Pulina, 2010). Outbound tourism is another indicator taken into account within the study in this paper. As Lin et al. (2015) states, studies published on outbound tourism demand are relatively small in number compared with the inbound tourism demand studies. Based on the importance of tourism and its contributions, it is important to determine the factors affecting tourism demand behaviour (Dragouni et al., 2016). Possible determinants of outbound tourism expenditures can be analysed both within a macro framework as well as micro framework. Macro-based studies use macroeconomic time series data in order to construct aggregate expenditure models of international tourism expenditures (Gozgor, Demir, 2018). By using surveys, micro-based studies try to examine "why", "how" and "on what" the tourists spend their money (Sheldon, 1990). From the macroeconomic point of view (Horvathova, 2014), to underline the connection between the GDP and outbound travel expenditure, we can use for example the findings of various authors (e.g. Gozgor, Demir, 2018, Vietze 2011), who show that economic factors (such as the gross domestic product per capita and trade openness), institutional quality (such as civil rights, political stability, effective governance, the level of corruption and freedom to speak), sociological factors (such as literacy rate and life expectancy), and tourism information affect the outbound tourism expenditures.

Inbound tourism, as an opposite of outbound tourism, is represented in the research within this paper by the Visitor Exports (taking into account the economic impact by foreign spending within the country by international tourists). The successful and sustainable development of inbound tourism necessitates a long-term commitment, balancing between tourism supply and tourist demands (Chen et al., 2018). Many studies in the literature analyse macroeconomic and non-economic determinants of inbound tourism. For instance, conflicts, political instability, security, and terrorism are also used as potential uncertainty sources affecting tourism development (Ghaderi et al., 2017; Saha and Yap 2014; Saha et al., 2017). Secondly, tourism economists consider an "economic framework" (known as market demand theory) to analyse tourism demand and expenditure (Demir, Gozgor, Paramati, 2019). The findings of several authors (e.g. Gholipour et al. 2016; Demir and Gozgor 2018) are also in parallel with the implications based on the conclusions of other papers listed in this study: the gross domestic product positively affects inbound tourism as expected. The expenditure behaviour of tourists from an inbound perspective also generates deeper insights from the interactions between spenders and service providers in the global tourism market (Mehran, Olya, 2019). The term 'visitor expenditure' has been clearly defined by the World Tourism Organization in 1991 as the total consumption expenditure made by a visitor or on behalf of visitors for and during his or her trip and stay at the destination (Syakir et al., 2015). Many studies have been conducted on visitor expenditure (Ashley, 2006; Meyer, 2007; Anyango et al., 2013). Visitor expenditure usually comprises of six main components such as transportation, lodging, food and beverage, gifts and souvenirs, entertainment and recreation (Syakir et al., 2015). The World Travel \& Tourism Council (VTTC) uses for the visitor expenditure the term Visitor Exports (Foreign spending). As it was mentioned above based on the data from WTTC (2019) the domestic travel spending generated $72.2 \%$ of direct travel and tourism GDP in 2019, which can be compared with the $27.7 \%$ for visitor exports (e.g. foreign visitor spending or international tourism receipts). Thus, the visitor exports in the inbound tourism still represents a very important part of the tourism from the economic point of view also.

Across many industries, productivity remains one of most comprehensive and reliable benchmark (Coelli et al., 2005, Carnicky et al., 2017). Productivity is a complex phenomenon and involves several components and using simple metrics to reflect the overall tourism productivity can be misleading for policy implications (Barros, Botti, Peypoch, Robinot, and Solonandrasana, 2011). Productivity is usually measured based on multiple inputs and outputs and, as mentioned, it provides a more comprehensive benchmark and reduces the subjectivity in comparing between different industry leaders (Barros et al., 2011). As stated by Assaf and Dwyer (2013, p.1234), with the tourism industry often perceived as a low productivity industry, productivity analysis is "crucial to 


\section{ENTREPRENEURSHIP AND SUSTAINABILITY ISSUES}

ISSN 2345-0282 (online) http://jssidoi.org/jesi/

2020 Volume 8 Number 1 (September)

http://doi.org/10.9770/jesi.2020.8.1(66)

evaluating tourism sustainability and reshaping tourism activities. There is a direct link between productivity and profitability, as when productivity increases, the tourism industry's competitiveness in labour, capital and real estate markets also increase". This approach is also supported by the authors Slusarczyk et al. (2016) and Kozicka et al. (2019). The results of the research conducted in New Zealand by Prayag et al. (2019) show that increased domestic and international visitor spending is followed by a measurable and significant increase in local GDP. They also concluded that exchange rates have a small but non-significant impact on international tourist spending. Belloumi (2010) examined a long-term dependence between tourism expenditure, currency exchange rates and gross domestic product and found unidirectional causality of tourism on Tunisian GDP growth. On the other hand, Oh (2005) investigated the contribution of tourism development to economic growth in South Korea, while unable to confirm a long-term relationship, he found a short-period dependence between increased income from tourism and economic growth. Several other authors (e.g. Brida \& Risso, 2009, Horvathova, 2015, Jaforullah, 2015) also found evidence for long- or short-term dependence between tourist expenditure and economic performance and growth.

\section{Methodology}

The main aim of this study is a research of effect between determinants of tourism development and macroeconomic indicators - national productivity, and a revelation of a space for a growth of OECD countries' productivity and their sustainable development, as well as a development of researched tourism sector. Multiple analytical trajectories were chosen to achieve aim of the research. The research also aimed at creating an international comparative platform. Consequently, the research sample consisted of all OECD countries. These countries were classified according to the international classification ISO 3166-1, code Alpha-3 with an emphasis on a period of 2010 - 2018. Tourism data (tourist spending) were obtained from World Travel \& Tourism Council database in fair value of trillion US dollars (USD). Productivity data were obtained from OECD database (productivity in USD in current prices, GDP per capita). Elimination of exchange differences influence by using data source unified in USD currency was performed (based on findings by authors Prayag et al. (2019), according to whom in case of exchange differences it was confirmed that exchange rates have a small, but non-significant impact on international tourist spending). Number of inhabitants was used in data standardization of individual countries. It represents a standard procedure in GDP case. Population data of individual countries for a specific period were obtained from World Bank database (WB, 2020). As Nolan, Rores a nd Thewissen (2019) suggest, the evolution of GDP per capita is still widely taken to be the central indicator of a country's economic performance and success in improving living standards over time. There was a similar procedure in standardizing 5 types of tourism spending (per 1,000 inhabitant in individual countries) that provided data comparability and usability for a statistical processing. The study focuses on the following types of spending according to World Travel \& Tourism Council: (1) Business Tourism Spending (BTS) - Spending on business travel within a country by residents and international visitors; (2) Domestic Tourism Spending (DTS) - Spending within a country by that country's residents for both business and leisure trips. Multi-use consumer durables are not included since they are not purchased solely for tourism purposes. This is consistent with total domestic tourism expenditure; (3) Leisure Tourism Spending (LTS) - Spending on leisure travel within a country by residents and international visitors; (4) Outbound Travel \& Tourism Expenditure (OTTE) - Spending outside the country by residents on all trips abroad. This is fully aligned with total outbound tourism expenditure; (5) Visitor Exports (Foreign spending) (VEFS) - Spending within the country by international tourists for both business and leisure trips, including spending on transport, but excluding international spending on education. This is consistent with total inbound tourism expenditure (wttc, 2020).

Productivity (Prod) is expressed in USD GDP per capita (per head of population) and data were obtained from OECD databases (OECD, 2020). 


\section{ENTREPRENEURSHIP AND SUSTAINABILITY ISSUES}

ISSN 2345-0282 (online) http://jssidoi.org/jesi/ 2020 Volume 8 Number 1 (September) http://doi.org/10.9770/jesi.2020.8.1(66)

Firstly, descriptive statistics was applied (mean, $95 \%$ confidence interval for mean (CI), median) and variance analysis (Kruskal-Wallis Rank Sum Test $(\mathrm{KW})$ ) that tested the differences of selected variables during individual years and between individual countries. Spearman's $\rho$ coefficient was used to apply context analysis. Regression analysis was applied in the next step. The assumptions tests support application of simple linear regression, were used at the very beginning. They evaluate an occurrence of significant outliers - Bonferroni Outlier Test (Fox, Weisberg, 2019). Then, effects were tested and the most appropriate model was selected (F Test for Individual Effects, Hausman Test for Panel Models (Wooldridge, 2010)) - Fixed and random effect model, and the Arrelano and White 1 (White, 1980) methods to estimate the coefficients in the case of significant heteroscedasticity. Presence of a significant heteroscedasticity was also tested - Breusch-Pagan Test (Breusch, Pagan, 1979).

The cluster analysis was realized by means of Ward's method. The number of clusters was estimated by using silhouette method - for average silhouette width (Struyf et al., 1997). Data calculated by arithmetic mean and standardized in interval $0-1$ (where 1 represents positive score) entered the cluster analysis. Programming language R v. 3.6.3 (Holding the Windsock) in R Studio was used to process the results.

\section{Results}

This chapter consists of all analytical procedures that led to the achievement of research aim. Tab. 1 provides an overview of primary statistical characteristics of variables together with a variance test that compares these variables during individual years and in the individual countries. Relations between individual variables were also considered. Regression and cluster analyses were applied in other procedures.

Table 1. Descriptive Statistics and Variance Test

\begin{tabular}{lcccccc}
\hline Statistics & BTS & LTS & DTS & OTTE & VEFS & Prod \\
\hline \hline Mean & 0.59 & 2.36 & 1.57 & 0.96 & 1.38 & 40580.31 \\
$95 \%$ CI & $0.54-0.64$ & $2.13-2.59$ & $1.45-1.69$ & $0.87-1.06$ & $1.19-1.58$ & $38823.28-42337.35$ \\
Median & 0.54 & 1.85 & 1.20 & 0.73 & 0.88 & 39547.67 \\
KW $\chi 2$ - Year & 1.85 & 3.79 & 1.2 & 2.9 & 4.68 & $23.201 * *$ \\
KW $\chi 2$ - Country & $317.28 * * *$ & $313.94 * * *$ & $319.65 * * *$ & $316.46^{* * *}$ & $313.84 * * *$ & $294.8 * * *$ \\
\hline \hline
\end{tabular}

Note $1: \mathrm{p}<0.1-+; \mathrm{p}<0.05-* ; \mathrm{p}<0.01-* * ; \mathrm{p}<0.001-* * *$

Note 2: CI - confidence interval for mean; KW - the Kruskal-Wallis test

Tab. 1 shows the highest average spending calculated per person (LTS) and the lowest average spending (BTS). It is obvious, when comparing mean 95\% CI and median, that there exist outliers in multiple variables. Median occurs in all cases out of CI, except of BTS and Prod. Non-parametric Kruskal-Wallis test, that identifies a difference only in a case of Prod variable in testing individual years, was used in significance tests of difference. Selected Variable mean (2010 - 2018) is provided in Apendix 1.

The category, countries, differed in all variables with a significance of $\alpha 0.001$. Correlation analysis was applied in order to provide a broader view on researched variables and relations between them. Non-parametric Spearman's correlation coefficient $\rho$ was used to confirm this correlation. Figure 1 displays a structure of variables as well as their relations. 

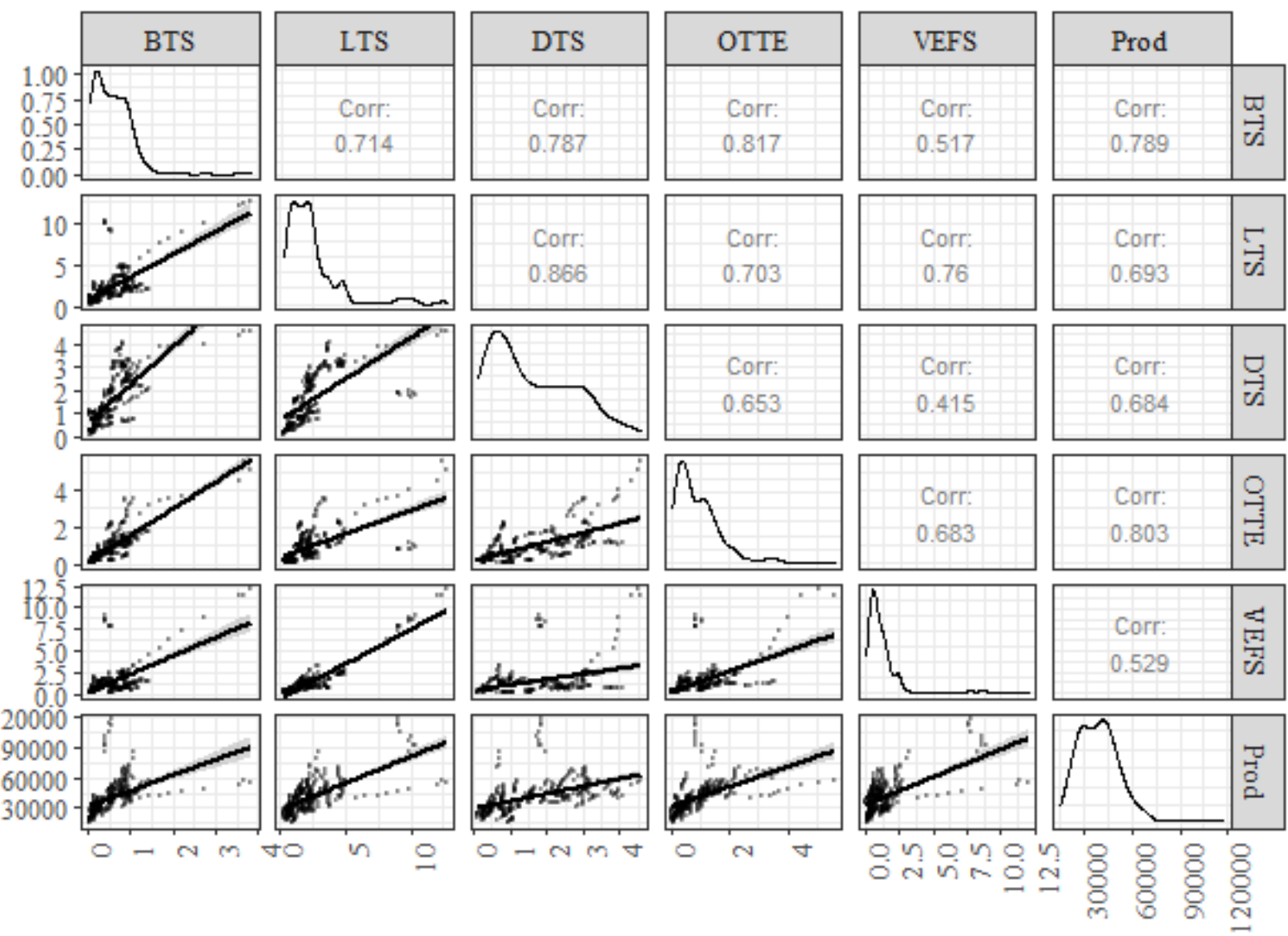

Fig. 1. Structure and relations of analysed variables

Source: own elaboration

Figure 1 illustrates matrix that shows variables' structure in its diagonal. Here, certain deviations from normal distribution that are caused by an obliqueness due to outliers' occurrence may be observed. Graphs that illustrates relations of analysed variables are visible below the diagonal, where outliers are evident. However, positive relationship is displayed on these graphs. Correlation coefficients are illustrated above the diagonal. These coefficients are significant in all of the cases. Similarly, they confirm an existence of a correlation spending of tourists and productivity, which is displayed in the last column of the matrix. Obviously, relatively high positive rates are presented in the matrix. Simultaneously, it is clear that variables of tourist spending correlate. Consequently, it is a positive correlation, i.e. when BTS increases, it is supposed that LTS will increase, as well. Another analyses' part focuses on regression models. Tab. 2 illustrates an evaluation of conditions in order to select the most appropriate regression method.

Models are labelled according to the independent variable (BTS, DTS, LTS, OTTE, VEFS), where the dependent variable is identical in all of the cases (productivity - Prod). 


\section{ENTREPRENEURSHIP AND SUSTAINABILITY ISSUES}

ISSN 2345-0282 (online) http://jssidoi.org/jesi/ 2020 Volume 8 Number 1 (September) http://doi.org/10.9770/jesi.2020.8.1(66)

Table 2. Assumptions' Testing for Simple Regression Analysis

\begin{tabular}{|c|c|c|c|c|c|}
\hline Assumptions & Model BTS & Model DTS & Model LTS & Model OTTE & Model VEFS \\
\hline Outliers & $8(2.47 \%)$ & $7(2.16 \%)$ & - & $77(2.16 \%)$ & - \\
\hline $\mathrm{F}$ & $39.48 * * *$ & $74.93 * * *$ & $50.46 * * *$ & $41.23 * * *$ & $59.53 * * *$ \\
\hline Hausman $\chi^{2}$ & $3.11+$ & $10.01 * *$ & 0.35 & 0.54 & $4.00 *$ \\
\hline $\mathrm{BP}$ & $131.26 * * *$ & 0.04 & $200.25 * * *$ & $41.12 * * *$ & $178.57 * * *$ \\
\hline Estimate & Random White 1 & Fixed & Random White 1 & Random White 1 & Fixed Arellano \\
\hline
\end{tabular}

Note 1: $\mathrm{p}<0.1-+; \mathrm{p}<0.05-* ; \mathrm{p}<0.01-* * ; \mathrm{p}<0.001$ - ***

Note 2: Outliers - Bonferroni Outlier Test; F - F test for individual effects; Hausman $\chi 2$ - Hausman Test; BP - Breusch-Pagan Test

Source: own elaboration

Tab. 3 shows evaluation of conditions based on which the models BTS, LTS and OTTE will be realized by means of the PLM Random Effect model and White 1 estimator. Model DTS will be realized by means of the PLM Fixed Effect as significant heteroscedasticity did not occur only in this model. Model VEFS will be calculated by the PLM Fixed Effect with Arellano estimator. Tab. 4 illustrates calculations' outputs.

Table 3. Regression Analysis Output

\begin{tabular}{llrrrrrr}
\hline Model & Coefficients & CI 2.5 \% & CI 97.5 \% & Estimate & Std. Error & $\mathrm{t}$ value & $\operatorname{Pr}(>|\mathrm{t}|)$ \\
\hline \hline \multirow{2}{*}{ Model BTS } & Constant & 29696.253 & 36741.76 & 33219 & 1790.4 & 18.554 & $<2.2 \times 10^{-16}$ \\
& BTS & 8731.753 & 14089.29 & 11410.5 & 1361.5 & 8.381 & $<2.2 \times 10^{-16}$ \\
\hline \multirow{2}{*}{ Model DTS } & Constant & - & - & - & - & - & - \\
& DTS & 11118.05 & 18991.25 & 15054.6 & 1999.9 & 7.5279 & $7.0 \times 10^{-13}$ \\
\hline \multirow{2}{*}{ Model LTS } & Constant & 26764.802 & 35233.25 & 30999.03 & 2001.22 & 15.49 & $<2.2 \times 10^{-16}$ \\
& LTS & 3095.821 & 4953.706 & 4024.76 & 696.86 & 5.7756 & $1.8 \times 10^{-8}$ \\
\hline \multirow{2}{*}{ Model OTTE } & Constant & 25664.23 & 33054.2 & 29359.2 & 2154.2 & 13.6287 & $<2.2 \times 10^{-16}$ \\
& OTTE & 9040.88 & 13259.1 & 11150 & 1948.9 & 5.7212 & $2.4 \times 10^{-8}$ \\
\hline \multirow{2}{*}{ Model VEFS } & Constant & - & - & - & - & - & - \\
& VEFS & 2183.454 & 4134.962 & 3159.2 & 1391.4 & 2.2706 & $2.4 \times 10^{-2}$ \\
\hline \hline
\end{tabular}

Source: own elaboration

All assumed relations seem to be significant. The lowest significance rate was determined in VEFS; it is possible to consider this relation as significant at the level of $\alpha 0.05$. All coefficients are positive. There is therefore possible to speak of an expected result. If the expenditures will grow, the GDP will also grow. There is a positive effect that highlighted the importance of tourism in terms of productivity.

Another analyses' part focuses on an application of cluster analysis that aims at evaluating interconnection among countries according to their highest similarity (inside the group), and also according to the highest variance (to other groups) within an evaluation of selected variables of tourist spending and productivity evaluation. Average values of individual variables are standardized from 0 to 1 , where 1 represents the best result. Subsequently, evaluations of tourist spending were corrected by arithmetic mean. There were created 2 new variables evaluation of tourist spending (ETS) and a variable that indicates productivity evaluation (EPROD). There is only one difference between Prod and EPROD - EPROD (in scale 0:1) is an evaluation of Prod variables (in interval scale). These variables entered into cluster analysis. In the first step, the most appropriate number of clusters was estimated by means of the Silhouette method. There were 4 clusters. Also, there were applied multiple other cluster analysis's models. However, the Ward method (0.9505) was the most appropriate one based on the Agglomerative coefficient. Figure 2 illustrates a dendrogram of a relation for evaluating tourist spending and productivity. 


\section{Cluster Dendrogram}

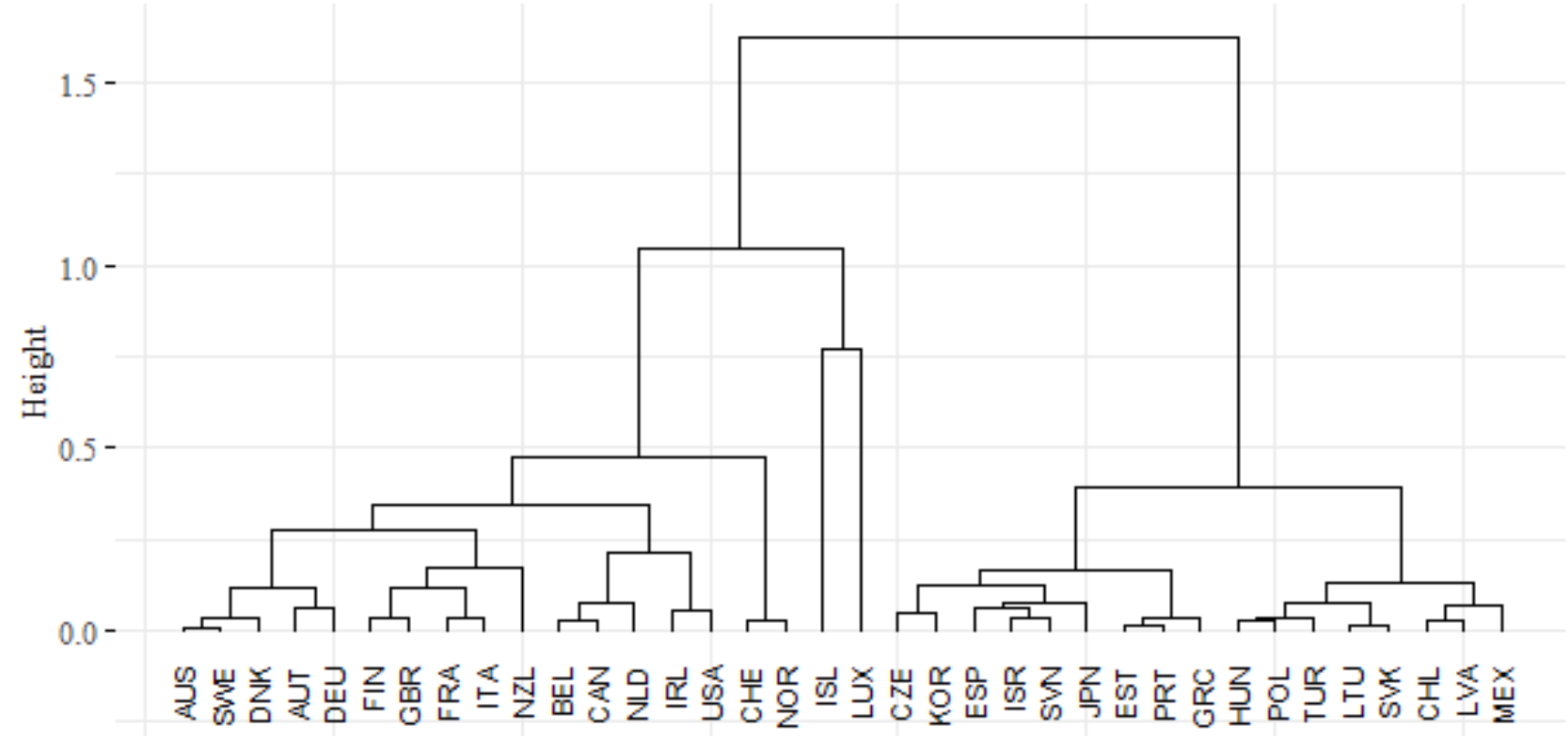

Fig. 2. Cluster dendrogram - relations ETS and EPROD

Source: own elaboration

Figure 2 visualizes links among countries in a researched relation of ETS and EPROD. The most appropriate division of countries was represented by 4 clusters, where the first cluster consists of the following countries: AUS, AUT, BEL, CAN, DEU, DNK, FIN, FRA, GBR, CHE, IRL, ITA, NLD, NOR, NZL, SWE and USA. Average value of ETS was at the level of 0.3209 and EPROD value reached 0.364 . The second cluster includes the following countries: CZE, ESP, EST, GRC, HUN, CHL, ISR, JPN, KOR, LTU, LVA, MEX, POL, PRT, SVK, SVN and TUR, where average value of ETS is 0.0937 and EPROD values is 0.1302 . The third cluster contains only one country, Iceland, while ETS value is 0.9847 and EPROD value is 0.3544 . Also, the last, the fourth cluster, involves only one country, Luxembourg, where ETS output is 0.565240 and EPROD output is 1.0. LUX and ISL are evaluated as extremes. It may be assumed, based on the findings, that the first cluster consists of such countries, which have values of both indicators at relatively high levels. ISL and LUX achieve high evaluations in both areas, and these countries are closer to the first cluster than the second one. The second cluster comprises countries with lower outputs' rates. Similarly, countries may be also considered on the basis of a specific level of interconnection, e.g. AUS is very similar to SWE in the analysed relation, and both countries are very similar to DNK. Figure 3 provides a clear demonstration of interconnecting evaluations of tourist spending and productivity. 


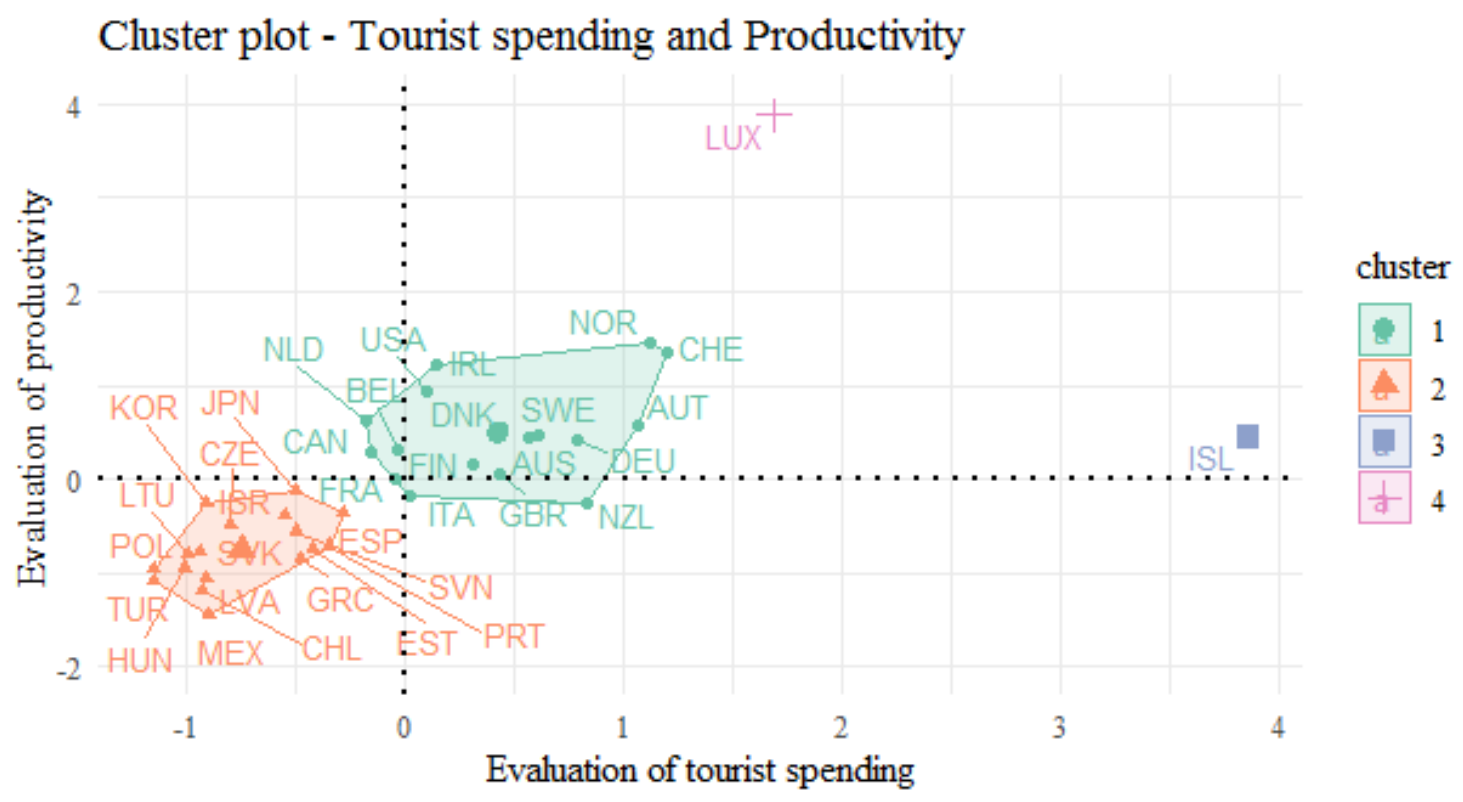

Fig. 3. Cluster plot - ETS and EPROD

Source: own elaboration

Figure 3 illustrates countries' relations in the analysed areas of given clusters. Lower left quadrant involves countries of the second cluster with low average evaluations of productivity, and also spending. Upper right quadrant identifies countries with positive evaluation.

\section{Discussion}

Analyses' results confirm existence of a relation between individual types of spending in tourism and between OECD countries' productivity. Leisure Tourism represents a category with the highest rate of spending, while category, Business Tourism, has the lowest rate of spending. These results are also related to a character of the individual spending types that are described in the part Theoretical Background in detail. It is also confirmed by many other studies, such as Parsons (2017) who suggests the impacts of budget limitation from employer's side during individual business trips in the study. It was found that it is important to observe differences between individual countries, while researching relations of tourist spending and productivity. Correlation matrix confirmed a relation between analysed variables of spending in the individual areas of tourism and productivity. It represents a very close relationship of positive correlation, while the closest dependency is between productivity and Outbound Tourism and the least close is in the category of Inbound Tourism. In case of Outbound Tourism, it may be caused by, for instance retro-causality, which assumes that higher productivity of a country leads to higher disponible incomes of its inhabitants. This may be divided into consumption and savings. If a consumption rate increases, spending also increases in the category of costly Outbound Tourism. On the other hand, Inbound Tourism influences country's productivity, but there absents retro-causality, which depends on disponible incomes intended for consumption in a country of tourist's origin.

Identical dependent variable, Productivity, is included in five independent models, which were created in researching of spending and productivity relations. Their (individual) relation with a productivity is important. Original assumption (based on the links of confirmed correlation coefficients) is confirmed. Consequently, it may be concluded that spending in the individual examined tourism categories influence countries' productivity in a positive way. Positive effect rate is not the same in each tourist spending variable. As regression function confirms, the spending of Business Tourism category influences productivity the most, which is also in 


\section{ENTREPRENEURSHIP AND SUSTAINABILITY ISSUES}

ISSN 2345-0282 (online) http://jssidoi.org/jesi/ 2020 Volume 8 Number 1 (September) http://doi.org/10.9770/jesi.2020.8.1(66)

accordance with the results of Carvalho et al. (2016) study. This tourism category spends the least average spending within OECD countries. The most average spending is typical of Leisure Tourism category. It is obvious that both tourism categories are at the third place right after Domestic Tourism Spending, when taking into consideration their influence on a productivity. This position results from spending character and their strong interconnection with the standard of a living and many socio-economic characteristics that are connected with economic parameters of a country (e.g. Crouch, 2013). The variables, Domestic Tourism and Leisure Tourism, represent categories with the highest potential to increase country's productivity in a successful tourism spending growth. This fact was determined in comparing the above-mentioned findings with those in the international studies by Massidda \& Etzo (2012); Tribe (2015); Kruger \& Douglas (2015); Scheyvens (2002); Samy (2016).

Another researched area of this study was a differentiation of analysed countries into groups with certain specificities in relation to researched topic - Tourism Spending that was connected to countries' productivity. Cluster analysis, which allowed division of countries into four main groups, was used. There were identified two countries, which are considered as extremes based on the results. These countries were Iceland (island nation with a very specific interest in tourism and economy that is adapted to geographical, natural and social specificities of the country) and Luxembourg (which has the highest productivity growth of the researched countries and which as Assaf and Tsionas (2018) state has experienced a significant increase in the number of international tourist arrivals and visitor spending. They stated that the country also ranks high on the tourism competitiveness and has invested significantly in the tourism industry over recent years.) Other countries were divided into two categories based on the results of cluster analysis, while variables were standardized (evaluated) average category of Tourism Spending in the countries a Productivity represented by the GDP of the countries.

The first group consists of countries with a relatively high rate of tourism spending and also with a relatively high productivity of a country. Tourism plays a significant role in economy of these countries, while these countries are very sensitive to incentives of tourism with regard to productivity. The second group involves countries with relative low GDP per person, but tourist spending is much lower per person as in the countries of the first group. It may signalize a different prioritization of countries' economies and different structural policy resulting from political aspects, economic position of a country, economic regional disparities, demographic structure, geographical conditions, country and regions' attractiveness.

The study's outputs represent an appeal to a formation of deeper structural analyses in order to create national and international comparative platform - national and international benchmarking indicators. It is a systematic, long procedure, where many international research teams would participate. This fact is confirmed by many foreign studies whose results emphasize a significance of a research that focuses on an influence of tourism spending on a country's economy, and an importance of reference models' development for countries' comparison. Also, it is supported by the study of Asaf \& Dwyer (2013), who appeal for a need to develop a complex international methodology of tourism benchmarking. The authors emphasize that quality tourism benchmarking requires a creation of a reference framework of such indicators that would be able to underpin heterogeneity of this sector and geographical specificities of the countries, as well. Similarly, these authors state that ignoring heterogeneity (i.e. differences in destination characteristics) may lead to bias in the productivity rankings of different countries. They also suggest that if a tourism of Africa, Europe and America is supposed to be compared, there needs to be developed multiple models that would reflect on heterogeneity of tourism systems in the countries and their specificities. In addition, Brida and Risso (2009) highlight significance of a research focusing on an influence of sustainable tourism spending, while the authors indicate a potential of multiple scenarios and their development. Their Impulse Response analysis shows that a positive shock in the tourism expenditure and the real exchange rate first produces negative effects and then a continuous and sustained positive impact. Jaforullah (2015) confirms positive effects of spending influence on a growth of economy. As the results of this study show, the long-run elasticity of real GDP with respect to real international tourism expenditure is estimated to be 0.4 , i.e. $1 \%$ growth in tourism will result in a $0.4 \%$ growth of the New Zealand economy. This finding implies that the 


\section{ENTREPRENEURSHIP AND SUSTAINABILITY ISSUES}

ISSN 2345-0282 (online) http://jssidoi.org/jesi/ 2020 Volume 8 Number 1 (September) http://doi.org/10.9770/jesi.2020.8.1(66)

New Zealand Government's policy to promote New Zealand as a preferred tourism destination in the key international tourism markets may boost its economic growth. These consequent facts emphasize an importance to solve this issue as in macroeconomic so in microeconomic sphere. It is important for a correct creation of policies, and even for a provision of sustainable tourism. The results of this study form a strong platform for subsequent researches. Simultaneously, these results represent an appeal to create quality national and international tourism databases that would support a development of given indicators and a creation of benchmarking models.

\section{Conclusion}

Tourism represents approximately one tenth of global GDP and it is also considered as one of the fastest growing segments of service sector. Similarly, one-third of all services is represented by tourism services, while employment rate in this sector is also very interesting from a global perspective. Tourism investments are characterized by relatively high profitability, while they are related as to an increase of a technical level of accommodation and catering facilities, so to a support of an infrastructure development with a positive influence on all segments and sectors, such as transport, trade, civil engineering, banking, telecommunication, culture, etc. Tourism has a multiplier effect on a business community and economy as such. Consequently, it supports a creation of new working places, and also capital accumulation and financial resources of sustainable development of economically weaker regions. Tourism's position, its development and relations to other sectors differ in the individual countries. In some countries, tourism is a long-term profiling factor of economic activities, while in others, it may play a supplementary role from a perspective of a country's economy development. It is given by a character of a country and its economic and political situation, attractiveness, population structure, etc. In the last decades, many countries have experienced a decrease of authentic, traditional economic sectors that leads to problem solving of sustainable tourism. As a consequence of this fact, it is very important to examine tourism parameters in relation to specific macroeconomic indicators and to research significant causal relations and quantify them. This would enable a realization of comparative analyses that may reveal new determinants of development and tourism sustainability. Also, these processes are influenced by economic crises, pandemics, other natural disasters and fortuitous events in the countries. These aspects motivated research team to create this study. Its primary aim is to research an influence of tourists' spending on a productivity of OECD countries, and consequently, to evaluate a potential of sector's sustainability. There were realized many analytical procedures with 5 selected variables that were examined during 2010 - 2018 in all of the OECD countries in order to achieve the study aim. The outputs of regression models confirmed an influence of tourists' spending on a productivity, where all of the variables that indicated spending were significant. The results of cluster analysis enabled a division of countries into four groups - two huge clusters and two clusters represented only by one country of selected sample. The countries with a higher rank are as follows: AUS, AUT, BEL, CAN, DEU, DNK, FIN, FRA, GBR, CHE, IRL, ITA, NLD, NOR, NZL, SWE, USA, ISL and LUX, while the countries with a lower rank are: CZE, ESP, EST, GRC, HUN, CHL, ISR, JPN, KOR, LTU, LVA, MEX, POL, PRT, SVK, SVN and TUR. The first group consists of countries with relatively high rate of tourism spending and also with relatively high productivity of a country. In these countries, tourism plays a significant role in economy. Also, these countries are more sensitive to incentives from tourism sector in relation to a productivity. The second group includes countries, whose GDP per person is relatively low, but also tourism spending per person is much lower than in the countries of the first group. These disparities signalize a different prioritization of countries' economies that may result from political aspects, economic position of a country, economic regional disparities, demographic structures, as well as geographical conditions and attractiveness of a country and its regions.

These findings provide a space for a deeper research of causal relations between determinants of tourism development and economic indicators, while they also create a platform for subsequent researches. The study's findings may help experts in a creation of concepts of national and regional strategic plans that focus on a sustainable development of regions, as well as a provision of sustainable tourism. This would be possible in case state-initiated activities would enable a systematic help to business community and all other subjects of tourism in 


\section{ENTREPRENEURSHIP AND SUSTAINABILITY ISSUES}

ISSN 2345-0282 (online) http://jssidoi.org/jesi/ 2020 Volume 8 Number 1 (September)

http://doi.org/10.9770/jesi.2020.8.1(66)

increasing services quality, expertise, support of regional development and competitiveness. Consequently, the study results make a significant contribution to policy creators and a development of international cooperation in this sphere. Similarly, the results represent a strong appeal for a creation of a quality database in each country in order to develop benchmarking indicators and other methods that would examine causal links between individual parameters of tourism.

\section{References}

Amir, S., Osman, M.M., Bachok, S., Ibrahim, M. 2015. Understanding domestic and international tourists' expenditure pattern in Melaka, Malaysia: result of CHAID analysis. Contemporary Issues in Management and Social Science Research, Edited by: Wickramasinghe, D; Hamid, AFA; Pirzada, K., Book Series: Procedia Social and Behavioral Sciences, 172: 390-397. https://doi.org/10.1016/j.sbspro.2015.01.386

Anyango, N. M., Van der Duim, R., Peters, K. 2013. Spending Of Dutch Tourists: The Locality of Money. Annals of Tourism Research, 43: 624-650. https://doi.org/10.1016/j.annals.2013.07.004

Ashley, C. 2006. How can governments boost the local economic impacts of tourism? Options and Tools: For SNV East and Southern Africa. London: Overseas Development Institute. Retrieved from: http://www.propoortourism.org.uk

Assaf, A. G., Dwyer, L. 2013. Benchmarking international tourism destinations. Tourism Economics, 19(6): $1233-1247$. https://doi.org/10.5367/te.2013.0354

Barros, C. P., Botti, L., Peypoch, N., Robinot, E., Solonandrasana, B. 2011. Performance of French destinations: Tourism attraction perspectives. Tourism Management, 32(1): 141-146. https://doi.org/10.1016/j.tourman.2010.01.015

Barros, C. P., Peypoch, N., Solonandrasana, B. 2009. Efficiency and productivity growth in hotel industry. International Journal of Tourism Research, 11(4): 389-402. https://doi.org/10.1002/jtr.711

Belloumi, M. 2010. The relationship between tourism receipts, real effective exchange rate and economic growth in Tunisia. International Journal of Tourism Research, 12(5): 550-560. https://doi.org/10.1002/jtr.774

Breusch, T., S., Pagan, A., R. 1979. A Simple Test for Heteroscedasticity and Random Coefficient Variation. Econometrica, 47(5): 12871294.

Brida, J. G., Risso, W. A. 2009. Tourism as a factor of long-run economic growth: An empirical analysis for Chile. European Journal of Tourism Research, 2(2): 178-185. ISSN: 1994-7658.

Carnicky, S., Megyesiova, S., Conkova, M., Zavadsky, C. 2017. Productivity development and convergence across the EU Member States. Economic Annals-XXI, 162(11-12): 13-17. https://doi.org/10.21003/ea.V162-03

Carvalho, P., Márquez, M. A., Díaz, M. 2016. International Business Tourism: a growth rate model. International Journal of Research in Tourism and Hospitality, 2(2). http://dx.doi.org/10.20431/2455-0043.0202003

Chen, H-S., Tsai, B.K., Liou, G.B., Hsieh, C.M. 2018. Efficiency Assessment of Inbound Tourist Service Using Data Envelopment Analysis. Sustainability. 10(6), Article Number: 1866, http://doi.org/10.3390/su10061866

Coelli, T. J., Rao, D. S. P., O'Donnell, C. J., Battese, G. E. 2005. An introduction to efficiency and productivity analysis. New York: Springer Science \& Business Media.

Cohen, E. 2010. Tourism, Leisure and Authenticity. Tourism Recreation Research, 35(1): 67-73. http://doi.org/10.1080/02508281.2010.11081620 


\section{ENTREPRENEURSHIP AND SUSTAINABILITY ISSUES}

ISSN 2345-0282 (online) http://jssidoi.org/jesi/ 2020 Volume 8 Number 1 (September)

http://doi.org/10.9770/jesi.2020.8.1(66)

Crouch, D., 2013. Leisure/tourism geographies: practices and geographical knowledge. London: Routledge, Taylor \& Francis. https://doi.org/10.4324/9780203350461

Demir E, Gozgor G. 2018. Does Economic Policy Uncertainty Affect Tourism? Annals of Tourism Research, 69: 15-17. https://doi.org/10.1016/j.annals.2017.12.005

Demir, E., Gozgor, G., Paramati, S. R. 2019. Do geopolitical risks matter for inbound tourism? Eurasian Business Review, 9(2): 183-191. https://doi.org/10.1007/s40821-019-00118-9

Dibra, M. 2015. Rogers Theory on Diffusion of Innovation-The Most Appropriate Theoretical Model in the Study of Factors Influencing the Integration of Sustainability in Tourism Businesses. Procedia - Social and Behavioral Sciences, 195: 1453-1462. https://doi.org/10.1016/j.sbspro.2015.06.443.

Dragouni, M., Filis, G., Gavriilidis, K., Santamaria, S. 2016. Sentiment, Mood and Outbound Tourism Demand. Annals of Tourism Research, 60(1): 80-96. http://dx.doi.org/10.1016/j.annals.2016.06.004

Fox, J., Weisberg, S. 2019. An R Companion to Applied Regression. Third Edition, California: SAGE

Ghaderi, Z., Saboori, B., Khoshkam, M. 2017. Does Security Matter in Tourism Demand? Current Issues in Tourism, 20(6): 552-565. https://doi.org/10.1080/13683500.2016.1161603

Gholipour HF, Tajaddini R, Nguyen J. 2016. Happiness and Inbound Tourism. Annals of Tourism Research, 57: $251-253$. https://doi.org/10.1016/j.annals.2015.12.003

Gozgor, G., Demir, E. 2018. The Effects of Economic Policy Uncertainty on Outbound Travel Expenditures. Journal of Competitiveness, 10(3): 5-15. https://doi.org/10.7441/joc.2018.03.01

Graburn, N.H.H. 1989. Tourism: The Sacred Journey. In: Smith, V.L. (Ed) Hosts and Guests: The Anthropology of Tourism. Philadelphia. The University of Pennsylvania Press, 2nd edition. ISBN 978-0812212808.

Horvathova, J., et al. 2015. Selection of key performance indicators of chosen industry and their application in formation of Creditworthy model. International Scientific Conference: Business Economics and Management (BEM2015). Book Series: Procedia Economics and Finance, 34: 360-367. https://doi.org/10.1016/S2212-5671(15)01641-X

Horvathova, J., Mokrisova, M., Suhanyiova, A. 2014. Analysis of cost of equity models in calculating economic value added of Slovak businesses. Political Sciences, Law, Finance, Economics and Tourism, Vol II. International Multidisciplinary Scientific Conferences on Social Sciences and Arts (SGEM 2014), 2: 35-42. https://doi.org/10.5593/sgemsocial2014/B22/S6.005

Jaforullah, M. 2015. International tourism and economic growth in New Zealand. Tourism Analysis, 20(4): 413-418. https://doi.org/10.3727/108354215X14400815080523

Kasim, A. 2006. The Need for Business Environmental and Social Responsibility in the Tourism Industry. International Journal of Hospitality \& Tourism Administration, 7 (1): 1-22. https://doi.org/10.1300/J149v07n01_01

Kozicka, K., Kot, S., Gede Riana, I. 2019. The efficiency of cooperation between the participants in the supply chain in the tourism-related branch of industry in relation to client satisfaction. Sustainability (Switzerland), 11(17), art. no. 4716. https://doi.org/10.3390/su11174716

Kruger, E.A., Douglas, A. 2015. Constraints to consumption of South Africa's national parks among the emerging domestic tourism market. Development Southern Africa, 32 (3): 303-319, https://doi.org/10.1080/0376835X.2015.1010712

Lin, V.S., Liu, AY., Song, HY. 2015. Modeling and Forecasting Chinese Outbound Tourism: An Econometric Approach. Journal of Travel \& Tourism Marketing, 32: 1-2, 34-49, https://doi.org/10.1080/10548408.2014.986011

Massidda, C. Etzo, I. 2012. The determinants of Italian domestic tourism: A panel data analysis. Tourism Management, 33 (3): 603-610. https://doi.org/10.1016/j.tourman.2011.06.017 


\section{ENTREPRENEURSHIP AND SUSTAINABILITY ISSUES}

ISSN 2345-0282 (online) http://jssidoi.org/jesi/ 2020 Volume 8 Number 1 (September)

http://doi.org/10.9770/jesi.2020.8.1(66)

Mehran, J., Olya, H.G.T. 2019. Progress on outbound tourism expenditure research: A review. Current Issues in Tourism, 22(20): 25112537. https://doi.org/10.1080/13683500.2018.1517734

Meyer, D. 2007. Pro-Poor Tourism: From Leakages to Linkages. A Conceptual Framework for Creating Linkages between the Accommodation Sector and 'Poor' Neighboring Communities. Current Issues in Tourism, 10(6): 558-583. https://doi.org/10.2167/cit313.0

Nicula, V., Elena, P.R. 2014. Business Tourism Market Developments. Procedia Economics and Finance. 16: 703-712, https://doi.org/10.1016/S2212-5671(14)00858-2.

Nolan, B., Roser, M. Thewissen, S. 2019. GDP Per Capita Versus Median Household Income: What Gives Rise to the Divergence Over Time and how does this Vary Across OECD Countries? Review of Income and Wealth, 65 (3): 465-494. https://doi.org/10.1111/roiw.12362

OECD, 2020. Productivity. Retrieved from: https://stats.oecd.org/

Oh, C.O. 2005. The contribution of tourism development to economic growth in the Korean economy. Tourism Management, 26(1): 39-44. https://doi.org/10.1016/j.tourman.2003.09.014

Okello, M.M, Kenana, L., Kieti, D, 2012. Factors influencing domestic tourism for urban and semiurban populations around Nairobi National Park, Kenya. Tourism Analysis, 17(1): 79-89. https://doi.org/10.3727/108354212X13330406124214

Papatheodorou, A, Rosselló, J., Xiao, H. 2010. Global economic crisis and tourism: consequences and perspectives. Journal of Travel Research, 49(1): 39.45. https://doi.org/10.1177/0047287509355327

Parsons, G.R. 2017. Travel Cost Models. In: Champ P., Boyle K., Brown T. (eds) A Primer on Nonmarket Valuation. The Economics of Non-Market Goods and Resources, vol 13. Springer, Dordrecht. https://doi.org/10.1007/978-94-007-7104-8_6

Prayag, G., Fieger, P., Rice, J. 2019. Tourism expenditure in post-earthquake Christchurch, New Zealand. Anatolia - International Journal of Tourism and Hospitality Research, 30(1): 47-60, https://doi.org/10.1080/13032917.2018.1496941

Pulina, M. 2010. Modelling and forecasting length of stay. Anatolia - International Journal of Tourism and Hospitality Research, 21(2): 305-321. https://doi.org/10.1080/13032917.2010.9687105

Ritchie, J.R.B., Crouch, G. I. 2003. The Competitive Destination: A Sustainable Tourism Perspective, USA, CABI Publishing.

Saha, S, Su, JJ, Campbell, N. 2017. Does Political and Economic Freedom Matter for Inbound Tourism? A Cross-national Panel Data Estimation. Journal of Travel Research, 56(2): 221-234. https://doi.org/10.1177/0047287515627028

Saha S, Yap G. 2014. The Moderation Effects of Political Instability and Terrorism on Tourism Development: A Cross-country Panel Analysis. Journal of Travel Research, 53(4): 509-521. https://doi.org/10.1177/0047287513496472

Samy, H. 2016. Exploring Factors that Influence Domestic Tourists' Satisfaction with Budget Hotel Services in Egypt. Journal of Tourism, Heritage \& Services Marketing, 2(2). http://doi.org/10.5281/zenodo.376344

Sawicki, B. 2016. Reflections on business tourism in the context of the monograph study "Science tourism from a visual sociology perspective". IDO MOVEMENT FOR CULTURE. Journal of Martial Arts Anthropology, 16(4): 42-46. https://doi.org/10.14589/ido.16.4.8

Scheyvens, R. 2002. Tourism for development: empowering communities. US: Prentice Hall.

Seghir, G.M., Mostefa, B., Abbes, S.M., Zakarya, G.Y. 2015. Tourism Spending-Economic Growth Causality in 49 Countries: A Dynamic Panel Data Approach. $2^{\text {nd }}$ Global Conference on Business, Economics, Management and Tourism. Ed. by: AI Iacob, 23: $1613-1623$. http://doi.org/10.1016/S2212-5671(15)00402-5

Sheldon, P.J. 1990. A Reviewof Tourism Expenditure Research. In: Cooper, C. (Eds.), Progress in Tourism, Recreation and Hospitality Management, (pp. 28-49). Belhaven Press: London. 


\section{ENTREPRENEURSHIP AND SUSTAINABILITY ISSUES}

ISSN 2345-0282 (online) http://jssidoi.org/jesi/ 2020 Volume 8 Number 1 (September)

http://doi.org/10.9770/jesi.2020.8.1(66)

Slusarczyk, B., Smolag, K., Kot, S. 2016. The supply chain of a tourism product. Actual Problems of Economics, $179(5)$ : $197-207$.

Stefko, R., Nowak, S. 2014. Cooperation Shrines of Europe in Regional Management and Development. Polish Journal of Management Studies, 10(2): 209-215. Retrieved from: https://pims.zim.pcz.pl/resources/html/article/details?id=187740

Struyf, A., Hubert, M., Rousseeuw., P. J. 1997. Clustering in an Object-Oriented Environment. Journal of Statistical Software, 1(4): 1-30. https://doi.org/10.18637/jss.v001.i04

Swarbrooke, J., Horner, S. 2001. Bussines Travel and Tourism, Butterworth \& Heineman. Oxford.

Syakir, A., Osman, M., M., Bachoka, S., Ibrahim, M. 2015. Understanding Domestic and International Tourists' Expenditure Pattern in Melaka, Malaysia: Result of CHAID Analysis. Procedia - Social and Behavioral Sciences, 172(27): 390-397. https://doi.org/10.1016/j.sbspro.2015.01.386

Tribe, J. 2015. The Economics of Recreation, Leisure and Tourism. London: Routledge, Taylor \& Francis. https://doi.org/10.4324/9781315769233

UNWTO. 2013. Sustainable Tourism for Development: Guidebook on enhancing capacities for Sustainable Tourism for development in developing countries. Retrieved from: http://www.ilo.org/wcmsp5/groups/public/ed_dialogue/sector/documents/publication/wcms_216669.pdf

Vietze, C. 2011. What's Pushing International Tourism Expenditures? Tourism Economics, 17(2): 237-260. https://doi.org/10.5367/te.2011.0039

WB, 2020. The World Bank. Retrieved from: https://data.worldbank.org/indicator/SP.POP.TOTL

White, H. 1980. A Heteroskedasticity-Consistent Covariance-Matrix Estimator and a Direct Test for Heteroskedasticity. Econometrica 48 (4): 817-838. Retrieved from: https://www.jstor.org/stable/1912934

Wooldridge, J. 2010. Econometric Analysis of Cross-Section and Panel Data. London: MIT press.

WTTC, 2020. World Travel \& Tourism Council. Retrieved from: https://tool.wttc.org/

WTTC. 2019. Travel and tourism economic impact 2019 - world. WTTC, London. Accessed 5 April 2020. Retrieved from: https://www.wttc.org/-/media/files/reports/economic-impact-research/regions-2019/world2019.pdf 
ENTREPRENEURSHIP AND SUSTAINABILITY ISSUES

ISSN 2345-0282 (online) http://jssidoi.org/jesi/ 2020 Volume 8 Number 1 (September)

http://doi.org/10.9770/jesi.2020.8.1(66)

Apendix 1. Selected Variable mean (2010 - 2018)

\begin{tabular}{|c|c|c|c|c|c|c|}
\hline Country & BTS & LTS & DTS & OTTE & VEFS & Prod \\
\hline AUS & 0.6383 & 3.2683 & 3.0596 & 1.3661 & 0.8470 & 47675.40 \\
\hline AUT & 0.8281 & 4.8013 & 3.0801 & 1.4677 & 2.5493 & 49317.55 \\
\hline BEL & 0.5409 & 1.5308 & 0.8277 & 2.0760 & 1.2440 & 45510.82 \\
\hline CAN & 0.7569 & 1.2542 & 1.5765 & 1.0117 & 0.4346 & 44887.44 \\
\hline CZE & 0.2402 & 1.0148 & 0.5086 & 0.4626 & 0.7463 & 32963.92 \\
\hline DEU & 0.7708 & 3.6683 & 3.8242 & 1.1648 & 0.6149 & 47036.19 \\
\hline DNK & 1.1983 & 1.8946 & 1.7456 & 1.6706 & 1.3472 & 48910.61 \\
\hline ESP & 0.3343 & 2.4174 & 1.2911 & 0.5223 & 1.4606 & 34858.35 \\
\hline EST & 0.4768 & 1.5420 & 0.5068 & 0.9145 & 1.5119 & 28926.41 \\
\hline FIN & 0.9108 & 2.3027 & 2.3690 & 1.0900 & 0.8445 & 43161.46 \\
\hline FRA & 0.5569 & 2.2938 & 1.9512 & 0.7259 & 0.8995 & 40592.10 \\
\hline GBR & 1.0745 & 2.1405 & 2.6534 & 1.2055 & 0.5616 & 41411.39 \\
\hline GRC & 0.1656 & 2.3858 & 1.0254 & 0.3248 & 1.5259 & 27411.13 \\
\hline HUN & 0.0931 & 0.8146 & 0.2648 & 0.2802 & 0.6429 & 25911.94 \\
\hline CHE & 0.8196 & 4.6404 & 3.1404 & 2.1243 & 2.3196 & 61677.69 \\
\hline CHL & 0.1593 & 0.8573 & 0.8255 & 0.1295 & 0.1911 & 22054.92 \\
\hline IRL & 0.9566 & 2.1454 & 0.6877 & 1.4053 & 2.4143 & 59721.46 \\
\hline ISL & 2.4895 & 9.3492 & 3.9647 & 3.9755 & 7.8740 & 47485.65 \\
\hline ISR & 0.2814 & 1.3925 & 0.8016 & 0.8204 & 0.8724 & 34670.92 \\
\hline ITA & 0.6237 & 2.4123 & 2.3188 & 0.5281 & 0.7172 & 37857.00 \\
\hline JPN & 0.5694 & 1.1550 & 1.5454 & 0.2111 & 0.1791 & 38757.75 \\
\hline KOR & 0.1751 & 0.6962 & 0.4721 & 0.4854 & 0.3992 & 36447.08 \\
\hline LTU & 0.1812 & 0.6486 & 0.3526 & 0.2704 & 0.4772 & 27983.70 \\
\hline LUX & 0.4764 & 9.6192 & 1.8344 & 0.8915 & 8.2612 & 100940.11 \\
\hline LVA & 0.1693 & 0.8227 & 0.4190 & 0.4183 & 0.5730 & 23959.28 \\
\hline MEX & 0.0679 & 1.1014 & 1.0346 & 0.0924 & 0.1347 & 18142.32 \\
\hline NLD & 0.5617 & 1.6327 & 1.1528 & 1.2309 & 1.0417 & 50324.57 \\
\hline NOR & 0.9663 & 3.0361 & 2.8367 & 3.1055 & 1.1656 & 63118.76 \\
\hline NZL & 0.9282 & 4.0835 & 3.1011 & 1.0334 & 1.9106 & 36673.00 \\
\hline POL & 0.1167 & 0.3253 & 0.1418 & 0.2132 & 0.3002 & 25812.82 \\
\hline PRT & 0.4115 & 2.2020 & 0.9502 & 0.4946 & 1.6633 & 29540.68 \\
\hline SVK & 0.2709 & 0.6524 & 0.4738 & 0.2141 & 0.4495 & 28673.45 \\
\hline SVN & 0.3138 & 1.8303 & 0.7575 & 0.5732 & 1.3867 & 31959.56 \\
\hline SWE & 1.1607 & 2.4257 & 2.2500 & 1.6297 & 1.3365 & 47901.39 \\
\hline TUR & 0.0822 & 0.5129 & 0.2780 & 0.0480 & 0.3171 & 23583.48 \\
\hline USA & 0.8920 & 2.1414 & 2.4290 & 0.4479 & 0.6044 & 55030.92 \\
\hline
\end{tabular}

Source: own elaboration

Acknowledgments

The authors thank the journal editor and reviewers for their guidance and constructive suggestions.

Last but not least, the authors thank the Research and Development Agency GAAA under the contract No. $21 / 2020$. 


\section{ENTREPRENEURSHIP AND SUSTAINABILITY ISSUES}

ISSN 2345-0282 (online) http://jssidoi.org/jesi/ 2020 Volume 8 Number 1 (September)

http://doi.org/10.9770/jesi.2020.8.1(66)

Prof. Beata GAVUROVA, Ph.D. is an expert in finance, financial analysis and financial risk management. She focuses in her research work on issues of measurement and performance management in various sectors, process management and process optimization, strategic and performance benchmarking. Her dominant research area is the development and testing in the management and performance measurement, the evaluation of methodologies and the preparation of an application platform for innovative management and performance measurement with the support of ICT. She led several national projects, has participated in many international projects targeting the innovative applications of ICT in the private and public sector.

ORCID ID: https://orcid.org/0000-0002-0606-879X

Assoc. Prof. Ladislav SUHÁNYI, Ph.D. is an Associate Professor in the field of Management at the University of Presov, Faculty of Management and he is a former Vice-Rector for International Relations and Marketing of the university. At present, he is a Deputy for International Research of the Faculty of Management. He obtained his PhD degree at the Faculty of Economics in Kosice in the field of Finance. He participated in several research, educational and development projects. His research areas are sustainable regional economy and management.

ORCID ID: orcid.org/0000-0002-6277-6117

Mgr. Martin RIGELSKY currently works at the Department of Marketing and International Trade at the Faculty of Management of the University of Prešov. His scientific activities include, in particular, research in the field of economics with a focus on public health and tourism. He deals secondarily with marketing and customer behaviour.

ORCID ID: orcid.org/0000-0003-1427-4689

Make your research more visible, join the Twitter account of ENTREPRENEURSHIP AND SUSTAINABILITY ISSUES:

@ Entrepr69728810

Copyright (C) 2020 by author(s) and VsI Entrepreneurship and Sustainability Center

This work is licensed under the Creative Commons Attribution International License (CC BY).

http://creativecommons.org/licenses/by/4.0/

c) (i) Open Access 